\title{
СУЧАСНІ ШЛЯХИ ВВЕДЕННЯ ЛІКАРСЬКИХ ПРЕПАРАТІВ ПРИ ВИКОНАННІ СЕРЦЕВО-ЛЕГЕНЕВОЇ ТА МОЗКОВОЇ РЕАНІМАЦІї НА ДОГОСПІТАЛЬНОМУ ЕТАПІ
}

\author{
ДВНЗ «Тернопільський державний медичний університет імені І.Я. Горбачевського МОЗ України», \\ м. Тернопіль, Україна
}

Виконання базових алгоритмів сучасного клінічного протоколу раптової зупинки кровообігу вимагає, зокрема, якнайшвидшого забезпечення венозного доступу. Водночас саме відсутність кровообігу є тим несприятливим фактором, який суттєво ускладнює, а нерідко й унеможливлює, успішну реалізацію даної методики, ламаючи при цьому всі ланки серцево-легеневої та мозкової реанімації, відповідно, зводячи ії̈ ефрективність до сратального мінімуму. Такі випадки, зокрема, спостерігаються у пацієнтів із раптовою зупинкою кровообігу на тлі гіповолемії тяжкого ступеня, гіпоксії, у наркоманів тощо.

Мета - дослідити та проаналізувати альтернативні внутрішньовенному шляхи введення медикаментів при раптовій зупинці кровообігу за умов діяльності бригади екстреної (швидкої) медичної допомоги.

Матеріали і методи. 3 використанням бібліосемантичного, аналітичного методів і методу системного аналізу проведено детальний аналіз альтернативних внутрішньовенному способів введення лікарських засобів, їх порівняльну характеристику, оцінено переваги та недоліки, зважаючи при цьому на їх практичну доступність, вартість, адаптацію до вікової характеристики постраждалих, які перебувають у стані клінічної смерті.

Результати. Після проведення детального аналізу методик та шляхів введення медикаментів при раптовій зупинці кровообігу лікарями екстреної (швидкої) медичної допомоги (Е(Ш)МД), зважаючи на важкість, а подекуди неможливість забезпечення внутрішньовенного доступу, слід вважати внутрішньокістковий доступ найбільш ефективним засобом введення медикаментів під час виконання реанімаційних заходів. Наступним за ефективністю, складністю проведення, особливо за умов масового випадку після використання класичного внутрішньовенного доступу, є внутрішньокістковий доступ.

На сьогодні цей спосіб вважається хорошою альтернативою іншим методам, оскільки при дотриманні нескладних технічних вимог досягається терапевтичний есрект від введених медикаментів, аналогічний тому, що й при внутрішньовенних інсузіях.

Основною перевагою внутрішньокісткового доступу, порівняно 3 досліджуваними (ендотрахеальний, внутрішньосерцевий, внутрішньоартеріальний), складними за технікою виконання, що загрожують розвитком значних ускладнень, $€$ можливість його застосування у немовлят та дітей молодшого віку, знайти вени в яких, як правило, достатньо важко. Також даний спосіб вважається хорошою альтернативою іншим методикам, тому що за дотримання нескладних технічних вимог при цьому досягається якісний терапевтичний ефект від введених медикаментів.

Висновки. Якісна теоретична підготовка, наявність необхідного сучасного медичного спорядження, практичне професійне освоєння стандартних і сучасних альтернативних методик донесення медикаментів при раптовій зупинці кровообігу лікарями Е(Ш)МД сприятимуть дотриманню основних положень клінічних протоколів лікування даного термінального стану, а в кінцевому результаті приведуть до зниження догоспітальної та ранньої госпітальної летальності.

КЛЮЧОВІ СЛОВА: серцево-легенева та мозкова реанімація; раптова зупинка кровообігу; внутрішньовенне введення ліків; пункція; катетеризація центральних вен; внутрішньокістковий доступ; внутрішньоартеріальний, внутрішньосерцевий та внутрішньотрахеальний шляхи введення медикаментів.

Одним із важливих моментів у якісному проведенні кваліфрікованих реанімаційних заходів $€$ надання своєчасної, адекватної, ефективної медикаментозної підтримки. Відомо, що виконання базових алгоритмів сучасного клінічного протоколу раптової зупинки кровообігу (РЗК) вимагає, зокрема, якнайшвидшого забезпечення венозного доступу $[1,5]$. Водночас саме відсутність кровообігу є тим несприятливим фрактором, який суттєво ускладнює, а нерідко й унеможливлює, успішну реалізацію даної методики, ламаючи при цьому всі ланки серцево-легеневої та мозкової реанімації, відповідно, зводячи її ефективність до фратального мінімуму. Такі випадки, зокрема, спостерігаються у пацієнтів із РЗК на тлі гіповолемії тяжкого ступеня, гіпоксії, в наркоманів тощо.

Все це зумовлює пошук інших, альтернативних способів донесення ліків до потерпілого, який перебуває в стані клінічної смерті, особливо на догоспітальному етапі, а саме в діяльності бригади 
екстреної (швидкої) медичної допомоги (Е(Ш)МД)) [2-4]. Не секрет, що в більшості випадків при наданні реанімаційної допомоги їй доводиться працювати в складних умовах (у темний час доби, на вулиці, на трасі, при значному скупченні людей, в обмеженому часі та просторі й т. д.).

Саме тому видається актуальним розглянути і проаналізувати основні шляхи введення медикаментів при РЗК, ознайомитись із сучасними альтернативними методиками, детально зупинившись на їх перевагах та недоліках.

Мета - дослідити та проаналізувати альтернативні внутрішньовенному шляхи введення медикаментів при РЗК за умов діяльності бригади екстреної (швидкої) медичної допомоги.

Матеріали і методи. 3 використанням бібліосемантичного, аналітичного методів і методу системного аналізу проведено детальний аналіз альтернативних внутрішньовенному способів введення лікарських засобів, їх порівняльну характеристику, оцінено переваги та недоліки, зважаючи при цьому на їх практичну доступність, вартість, адаптацію до вікової характеристики постраждалих, які перебувають у стані клінічної смерті.

Результати дослідження та їх обговорення.

\section{Внутрішньокістковий доступ}

Останнім часом даний метод набуває все більшої популярності, оскільки він вважається хорошою альтернативою та доступний у тих випадках, коли інші способи донесення ліків до організму технічно не можливі або ж існують протипоказання до їх використання. Частіше застосовується в дітей, молодших 3 років, однак при необхідності може використовуватись у всіх вікових групах $[6,7]$. Швидкість введення та терапевтичний ефект інфрузійного розчину через внутрішньокістковий доступ аналогічні внутрішньовенному. Губчаста речовина кістки чудово кровопостачається та є продовженням венозного русла, а тому може використовуватися для введення рідини і лікарських препаратів.

Внутрішньокістковий доступ здійснюється за допомогою шприц-пістолета (бонін'єктора) для внутрішньокісткових ін'єкцій (рис. 1, 2).

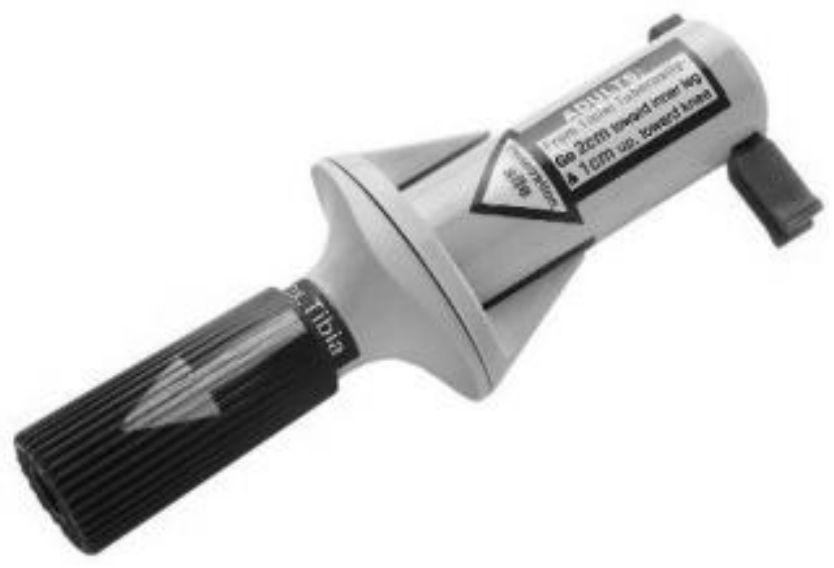

Puc. 1. Загальний вигляд бонін'єктора
Місце ін'єкції. Кращим місцем $€$ передньовнутрішня поверхня великогомілкової кістки, оскільки вона розташована відразу під шкірою і проста для ідентифрікації. Також можуть використовуватися передня поверхня стегна і гребінь клубової кістки, груднина, п'яткова кістка $[8,11]$.

Не можна використовувати кістки 3 наявними переломами й остеомієлітом.

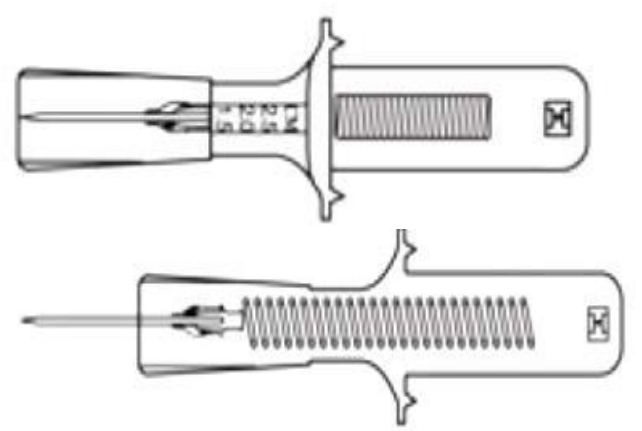

Puc. 2. Внутрішня структура бонін'єктора

\section{Техніка проведення:}

1. На шкалі пістолета слід вибрати необхідну глибину проникнення, відгвинтивши рукав від циліндричного кожуха (рис. 3, табл.).

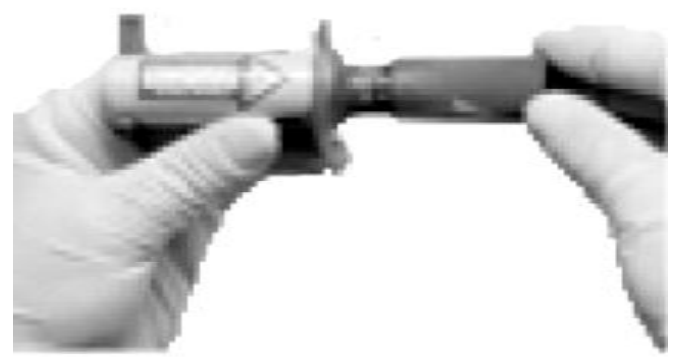

Puc. 3. Вибір необхідної глибини проникнення голки

2. Найбільш схвалене та задіяне для введення голки місце - передня медіальна поверхня проксимальної частини тіла великогомілкової кістки (верхня суглобова поверхня великогомілкової кістки).

Шляхом пальпації віднайти горбистість великогомілкової кістки безпосередньо під коліном.

Визначити верхню суглобову поверхню великогомілкової кістки - місце для введення (вона розміщена приблизно на 1-2 см медіальніше від горбистості великогомілкової кістки).

3. Обробити місце ін'єкції.

4. Під кутом $90^{\circ}$ дещо каудальніше розташувати провідною рукою передню частину бонін'єктора у точки вступу, при цьому утримуючи і сильно натискаючи на задню частину. Іншою рукою міцно підтримувати цю ногу, намагаючись не торкатися до неї ззаду. При необхідності можна скористатися валиком з рушника для додаткової опори ноги.

5. Відстібнути від пристрою запобіжну засувку з одночасним натисканням на обидві сторони (рис. 4). 
Таблиця. Визначення розміру та глибини введення голки бонін'єктора залежно від віку хворого

\begin{tabular}{|l|c|c|}
\hline \multicolumn{1}{|c|}{ Вік хворого } & Розмір голки & Глибина проникнення голки, см \\
\hline Дорослі (>12 років) & $15 \mathrm{G}-$ синій колір & 2,5 \\
\hline Діти від 6 до 12 років & $18 \mathrm{G}-$ червоний колір & 1,5 \\
\hline Діти від 3 до 6 років & $18 \mathrm{G}-$ червоний колір & $1,0-1,5$ \\
\hline Діти від 0 до 3 років & $18 \mathrm{G}-$ червоний колір & $0,5-0,7$ \\
\hline
\end{tabular}

6. Привести бонін'єктор у готовність, притиснувши задню частину до обох рукояток кожуха (рис. 5).

7. Забрати бонін'єктор і відокремити голку троакара від фрутляра (рис. 6).

8. Витягнути троакар-стилет і відокремити його від голки. В кістці повинна залишитися тільки канюля голки (рис. 7).

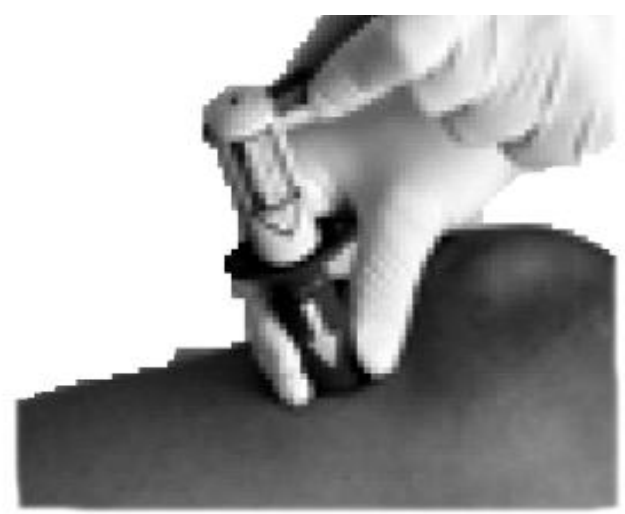

Puc. 4. Локалізація введення голки бонін'єктора

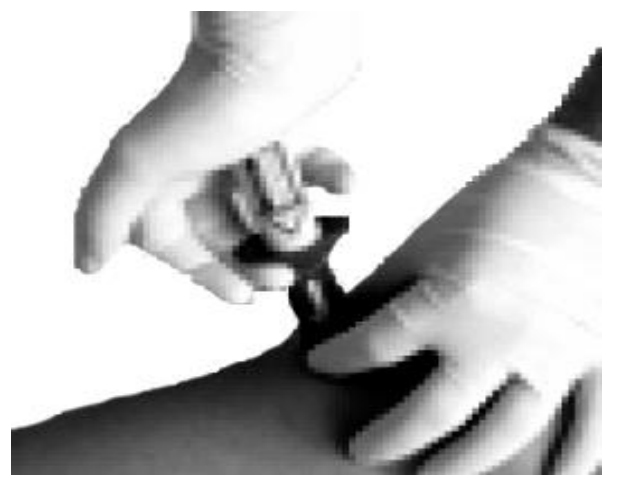

Рис. 5. Приведення бонін'єктора в готовність

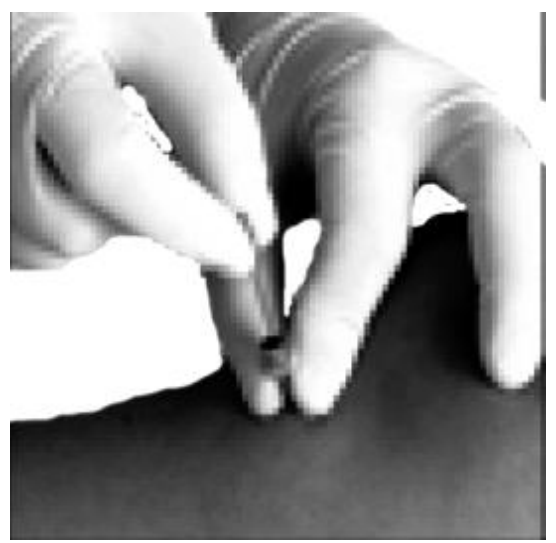

Puc. 6. Відокремлення голки троакара від футляра
9. Переконатися в правильному введенні, зробивши спробу ввести рідину. Рідина повинна вливатися легко, без проникнення із судин у тканини.

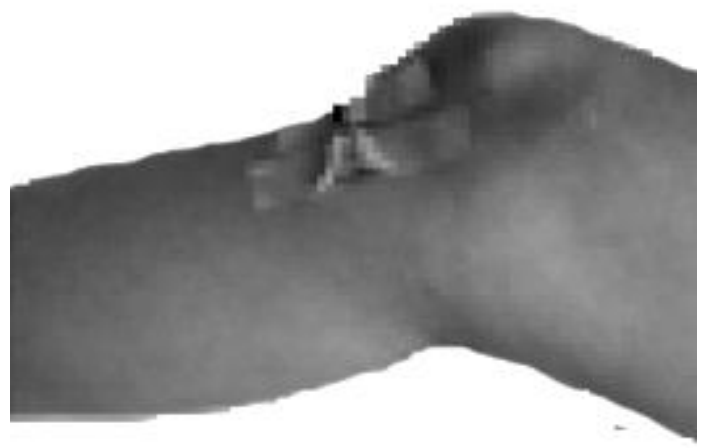

Рис. 7. Фіксація голки на тілі пацієнта

10. Забезпечити пристрою надійний упор і стабільність, використовуючи запобіжну засувку.

11. Ліки вводяться під невеликим тиском вручну за допомогою шприців або шляхом роздування манжетки навколо інфузійного мішка.

12. Якщо введення не увінчалося успіхом, процедуру повторюють на іншій нозі.

Бонін'єктор залишається на місці протягом кількох годин. Внутрішньокістковий спосіб інфузії повинен бути замінений на традиційний внутрішньовенний якомога швидше.

\section{Ендотрахеальний доступ}

Цей метод заслуговує на увагу як один із дієвих, хоча й менш ефективних способів донесення ліків до організму постраждалого. За своєю складністю і технікою виконання поділяється на два способи. Перший-достатньо доступний і здійснюється шляхом проведення конікопункції. Другий - технічно більш складний, оскільки досягається за рахунок надходження медикаментів через ендотрахеальну трубку, що вимагає якісної інтубації трахеї, якою, на жаль, професійно володіють далеко не всі лікарі Е(Ш)МД. Внутрішньотрахеальний шлях має ряд своїх особливостей та пересторог. По-перше, терапевтичну дозу препаратів (наприклад, розчину адреналіну) потрібно збільшити в 5-6 разів. По-друге, препарати вводять після розведення в дистильованій воді (або воді для ін'єкцій), оскільки, враховуючи вищу від цієї рідини осмолярність плазми, даний розчин швидше всмоктуватиметься через альвеоли, потрапляючи до вінцевих судин, 
створюючи при цьому концентрацію майже ідентичну, що й при внутрішньовенному введенні [8, 9]. Недоліками даної методики $€$ наявність рідини в дихальних шляхах як механічного подразника, а також, згідно з проведеними дослідженнями, при цьому відбувається часткове руйнування сурфактанта.

\section{Внутрішньоартеріальний доступ}

Внутрішньоартеріальний метод - достатньо ефективний спосіб введення ліків на етапі СЛМР, який вимагає чітких знань топографічної анатомії за умови абсолютної відсутності пульсації. Технічно доступною і безпечною для виконання пункції та катетеризації є стегнова артерія $[10,12]$.

\section{Внутрішньосерцевий доступ}

Внутрішньосерцевий шлях введення лікарських засобів - це «шлях відчаю», що застосовується лише при неможливості введення іншим способом. Для цього шприцом 3 довгою (10 см) голкою проводять пункцію в IV міжребер'ї зліва на 2 см назовні від лівого краю груднини (рис. 8).

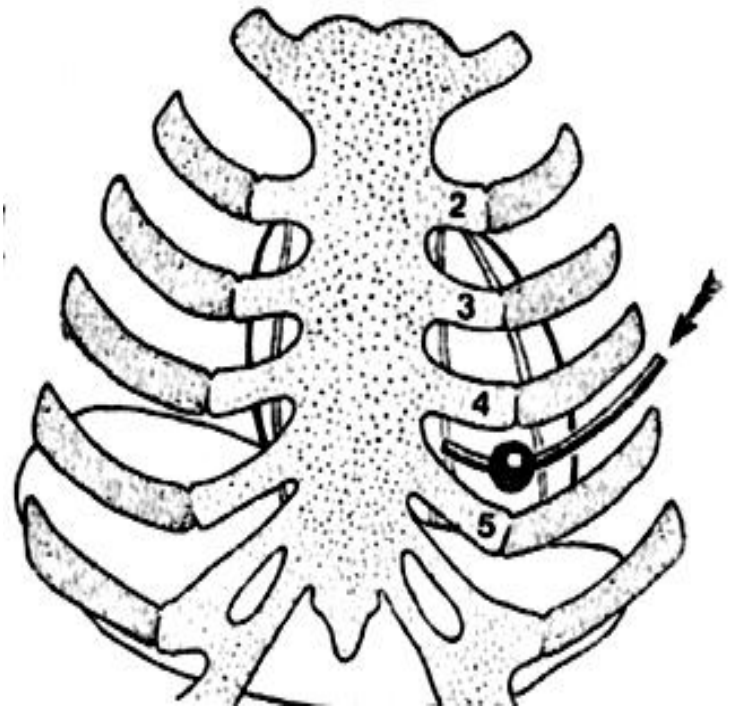

Рuc. 8. Точка введення голки при виконанні внутрішньовенних ін'єкцій

Контроль за розміщенням голки в порожнині серця обов'язковий, оскільки введення адреналіну в серцевий м'яз може викликати розвиток некрозу. В 40 \% випадків під час пункції спостерігається ушкодження крупних коронарних артерій, тому, за можливості, від внутрішньосерцевих ін'єкцій слід утримуватися. За даними рекомендацій Європейської ради ресусцитації від 2012 р., у зв'язку з частими ускладненнями ця методика не рекомендована, а на сьогодні використовується дуже рідко.

Після проведення детального аналізу методик та шляхів введення медикаментів при РЗК лікарями Е(Ш)МД, зважаючи на важкість, а подекуди неможливість забезпечення внутрішньовенного доступу, слід вважати внутрішньокістковий доступ найбільш ефективним засобом введення медикаментів під час виконання реанімаційних заходів. Наступним за ефективністю, складністю проведення, особливо за умов масового випадку після використання класичного внутрішньовенного доступу, є внутрішньокістковий доступ.

Основною перевагою внутрішньокіскового доступу, порівняно з досліджуваними (ендотрахеальний, внутрішньосерцевий, внутрішньоартеріальний), складними за технікою виконання, що загрожують розвитком значних ускладнень, є можливість його застосування у немовлят та дітей молодшого віку, знайти вени в яких, як правило, достатньо важко. Також даний спосіб вважається хорошою альтернативою іншим методикам, тому що за дотримання нескладних технічних вимог при цьому досягається якісний терапевтичний ефект від введених медикаментів.

\section{Висновки}

Якісна теоретична підготовка, наявність необхідного сучасного медичного спорядження, практичне профресійне освоєння стандартних та сучасних альтернативних методик донесення медикаментів при РЗК лікарями Е(Ш)МД сприятимуть дотриманню основних положень клінічних протоколів лікування даного термінального стану, а в кінцевому результаті приведуть до зниження догоспітальної та ранньої госпітальної летальності.

Перспективи подальших досліджень. Плануються дослідження і доведення ефективності від застосування альтернативних інтубації трахеї сучасних способів забезпечення прохідності дихальних шляхів для проведення якісної адекватної штучної вентиляції легень при тяжких формах гострої дихальної недостатності, в тому числі зупинці дихання.

\section{Список літератури}

1. Богомольний Б. Р. Медицина екстремальних ситуацій / Б. Р. Богомольний, В. В. Кононенко, П. М. Чув. - Одеса : Одес. держ. мед. ун-т, 2012. - С. 67-81, 173-193.

2. Дубицький А. Ю. Медицина катастроф / А. Ю. Дубицький, І. О. Семенов, Л. П. Чепкий. - К. : КУРС, 2013. С. $42-49$.

3. Компанець В. С. Медицина надзвичайних ситуацій / В. С. Компанець, Н. Д. Корольова. - К. : Вінниця, 2009. C. $108-140$.

4. Екстрена медична допомога: догоспітальний етап - алгоритми маніпуляції (базовий рівень) / [Г. Г. Рощін, А. А. Гудима, В. Ю. Кузьмін та ін.]. - К., 2012. - 84 с.

5. Медицина невідкладних станів: швидка і невідкладна медична допомога / [І. С. Зозуля, А. В. Вершигора, В. І. Боброва та ін.] ; за ред. І. С. Зозулі. - К. : ВСВ «Медицина», 2012. - 728 с. 
6. Медицина катастроф / [В. І. Гридасов, В. М. Ковальов, М. В. Катрич та ін.]. - Харків : Вид-во НФаУ ; Золоті сторінки, 2008. - С. 33-36.

7. Медицина надзвичайних ситуацій. Організація надання екстреної медичної допомоги : підручник / [В. С. Тарасюк, М. В. Матвійчук, І. В. Паламар та ін.]. - К. : Медицина, 2011. - 526 с.

8. Організація і надання екстреної медичної допомоги населенню в надзвичайних ситуаціях : навч. посіб. I [В. С. Тарасюк, І. М. Азарський, М. В. Матвійчук та ін.]. - Вінниця, 2006. - 156 с.

9. Медицина катастроф / [Г. О. Черняков, І. В. Кочін, П. І. Сидоренко та ін.]. - К. : Здоров'я, 2013. - 352 с.

10. Надання невідкладної допомоги при розвитку термінальних станів на догоспітальному етапі : практичні рекомендації / [В. Г. Рожнов, Н. І. Винник, О. С. Лавренко та ін.]. - Полтава : УМСА, 2008. - 146 с.

11. Про екстрену медичну допомогу : Закон України від 5 липня 2012 р. № 5081-VI.

12. Протоколи з надання екстреної медичної допомоги у разі невідкладних станів : посібник / [В. Ф. Москаленко, Г. Г. Рощін, Л. М. Анкін та ін.] ; за ред. В. Ф. Москаленка та Г. Г. Рощіна. - К. : Фарм Арт, 2011. - 112 с.

\section{References}

1. Bohomolnyi, B.R., Kononenko, V.V., \& Chuv, P.M. (2012). Medytsyna ekstremalnykh sytuatsii [Medicine of extreme situations.]. Odesa: Odes. derzh. med. un-t [in Ukrainian].

2. Dubytskyi, A.Yu., Semenov, I.O., \& Chepkyi, L.P. (2013). Medytsyna katastrof [Medicine of catastrophes]. Kyiv: "KURS" [in Ukrainian].

3. Kompanets, V.S. \& Korolova, N.D. (2009). Medytsyna nadzvychainykh sytuatsii [Emergency medicine]. Kyiv: Vinnytsia [in Ukrainain].

4. Roshchin, H.H., Hudyma, A.A., \& Kuzmin, V.Yu. (2012). Ekstrena medychna dopomoha: dohospitalnyi etap alhorytmy manipuliatsii (bazovyi riven). [Algorithms for manipulation: baseline. Emergency medical care: pre-hospital stage]. Kyiv [in Ukrainian].

5. Zozulia, I. S. (Ed.) Zozulia, I.S., Vershyhora, A.V. \& Bobrova, V.I. (2012). Medytsyna nevidkladnykh staniv: shvydka i nevidkladna medychna dopomoha [Medical emergencies: rapid and urgent medical care]. Kyiv: VSV "Medytsyna" [in Ukrainian].

6. Hrydasov V.I., Kovalov V.M., Katrych M.V. (2008). Medytsyna katastrof [Medical disasters]. Kharkiv: "Zoloti storinky" [in Ukrainian].

7. Tarasiuk, V.S., Matviichuk, M.V., Palamar, I.V., Korolova, N.D., Kuchanska, H.B., Novytskyi, N.O. (2011). Medytsyna nadzvychainykh sytuatsii. Orhanizatsiia nadannia ekstrenoi medychnoi dopomohy: Pidruchnyk. [Emergency medicine. Organization of provision of emergency medical aid. Textbook]. Kyiv: «Medytsyna» [in Ukrainian].

8. Tarasiuk, V.S., Azarskyi, I.M., Matviichuk, M.V., Korolova, N.D., Poliarush, V.V., Shpakova, N.A., Kryvetska, N.V. (2006). Orhanizatsiia i nadannia ekstrenoi medychnoi dopomohy naselenniu $v$ nadzvychainykh sytuatsiiakh [Organization and provision of emergency medical aid to the population in emergencies]. Vinnytsia [in Ukrainian].

9. Cherniakov H.O., Kochin I.V., Sydorenko P.I. (2013). Medytsyna katastrof. [Medical disasters]. Kyiv: "Zdorovia" [in Ukrainian].

10. Rozhnov, V.H., Vynnyk, N.I., Lavrenko, O.S., Tkach, L.I., Tsiluiko, O.V., Andrieieva, N.A. (2008). Nadannia nevidkladnoi dopomohy pry rozvytku terminalnykh staniv na dohospitalnomu etapi [Provision of emergency care in the development of terminal conditions at the pre-hospital stage]. Poltava: "UMSA" [in Ukrainian].

11. Zakon Ukrainy vid 5 lypnia 2012 roku № 5081-VI "Pro ekstrenu medychnu dopomohu" - Law of Ukraine of July 5, 2012 No. 5081-VI "On Emergency Medical Aid".

12. Moskalenko, V.F., Roshchin, H.H., \& Ankin, L.M. (2011) Protokoly z nadannia ekstrenoi medychnoi dopomohy u razi nevidkladnykh staniv [Protocols for the provision of emergency medical care in case of urgent conditions: Manual]. Kyiv: "Farm Art" [in Ukrainian].

\section{СОВРЕМЕННЫЕ ПУТИ ВВЕДЕНИЯ ЛЕКАРСТВЕННЫХ ПРЕПАРАТОВ ПРИ ВЫПОЛНЕНИИ СЕРДЕЧНО-ЛЕГОЧНОЙ И МОЗГОВОЙ РЕАНИМАЦИИ НА ДОГОСПИТАЛЬНОМ ЭТАПЕ}

Р.М. Ляхович, М.Я. Джус, Я.М. Кицак, А.К. Бадрах, В.Н. Савчук, П.П. Новикова

гВУЗ «Тернопольский государственный медицинский университет имени И.Я. Горбачевского МЗ Украины», г. Тернополь, Украина

Выполнение базовых алгоритмов современного клинического протокола внезапной остановки кровообращения требует, в частности, скорейшего обеспечения венозного доступа. В то же время именно отсутствие кровообращения является тем неблагоприятным фрактором, который существенно усложняет, а зачастую исключает, успешную реализацию данной методики, ломая при этом все звенья сердечно-легочной и мозговой реанимации, соответственно, сводя ее эффективность до рокового минимума. Такие случаи, в частности, наблюдаются у пациентов с внезапной остановкой кровообращения на фоне гиповолемии тяжелой степени, гипоксии, у наркоманов и тому подобное.

Цель - исследовать и проанализировать альтернативные внутривенному пути введения медикаментов при внезапной остановке кровообращения в условиях работы бригады экстренной (скорой) медицинской помощи.

Материалы и методы. С использованием библиосемантического, аналитического методов и метода системного анализа проведено детальный анализ альтернативных внутривенному способов введения 
лекарственных средств, их сравнительную характеристику, оценено преимущества и недостатки, учитывая при этом их практическую доступность, стоимость, адаптацию к возрастной характеристике пострадавших, находящихся в состоянии клинической смерти.

Результаты. После проведения детального анализа методик и путей введения медикаментов при внезапной остановке кровообращения врачами экстренной (скорой) медицинской помощи (Э(С)МП), учитывая тяжесть, а иногда невозможность обеспечения внутривенного доступа, следует считать внутрикостный доступ наиболее эфрфективным средством введения медикаментов во время выполнения реанимационных мероприятий. Следующим по эффективности, сложности проведения, особенно в условиях массового случая после использования классического внутривенного доступа, является внутрикостный доступ.

На сегодня этот способ считается хорошей альтернативой другим методам, поскольку при соблюдении несложных технических требований достигается терапевтический эфрфект от введенных медикаментов, аналогичный тому, что и при внутривенных инорузия.

Основным преимуществом внутрикостного доступа, в сравнении с исследуемыми (эндотрахеальный, внутрисердечный, внутриартериальный), сложными по технике выполнения, которые угрожают развитием значительных осложнений, является возможность его применения у новорожденных и детей младшего возраста, найти вены у которых, как правило, достаточно сложно. Также данный способ считается хорошей альтернативой другим методикам, так как при соблюдении несложных технических требований при этом достигается качественный терапевтический эффрект от введенных медикаментов.

Выводы. Качественная теоретическая подготовка, наличие необходимого современного медицинского снаряжения, практическое профессиональное освоение стандартных и современных альтернативных методик донесения медикаментов при внезапной остановке кровообращения врачами Э(С)МД будут способствовать соблюдению основных положений клинических протоколов лечения данного терминального состояния, а в конечном итоге приведут к снижению догоспитальной и ранней госпитальной летальности.

КЛЮЧЕВЫЕ СЛОВА: сердечно-легочная и мозговая реанимация; внезапная остановка кровообращения; внутривенное введение лекарств; пункция; катетеризация центральных вен; внутрикостный доступ; внутриартериальный; внутрисердечный и внутритрахеальный пути введения медикаментов.

\section{MODERN WAYS OF INJECTION MEDICAL PRODUCTS WHILE PERFORMING CARDIOPULMONARY AND CEREBRAL RESUSCITATION IN THE PREHOSPITAL PHASE}

R. M. Liakhovych, M. Ya. Dzus, Ya. M. Kitsak, O. K. Badrah, V. M. Savchuk, P. P. Novikova

I. Horbachevsky Ternopil State Medical University

The aim of the work - to investigate and analyze alternative to the intravenous route of administration of medications at sudden stoppage of blood activities in terms of teams of emergency medical aid.

Materials and Methods. We conducted the detailed analysis of alternative methods of pre-intravenous methods of administering drugs, their comparative characteristics, advantages and disadvantages, taking into account their practical availability, cost, adaptation to the age profile of victims in a state of clinical death. Considerable attention is directed to the using of modern, simple and highly effective method of intraosseous injection of drugs using bon injectors.

Results. A detailed analysis of the methods and ways of introduction of medicines at sudden stoppage of blood circulation by the doctors of emergency medical care produced that internally-osseous access is the most effective method of injection medications during the performance resuscitation. Next in efficiency, complexity of implementation is internally bone access.

Today this method is considered a good alternative to other methods, are achieved the therapeutic effect of drugs, similar to that with intravenous infusion.

The main advantage of internally bone access, compared to the studied (endotracheal, internally of the heart, intra-arterial), which are complex in technique and threaten the development of significant complications, is the possibility of its use for infants and young children. Also, this method is a good alternative to other techniques because is achieved high-quality therapeutic effect of medicines.

Conclusions. High-quality theoretical training, the availability of the necessary modern medical equipment, practical professional development standard and modern alternative methods of injection medicines at sudden stoppage of blood circulation by doctors of emergency medical care will promote to perform the basic tenets of clinical protocols of treatment of the terminal condition and, consequently, will eventually lead to decrease in prehospital and early hospital mortality.

KEY WORDS: cardiopulmonary and cerebral resuscitation; sudden cardiac arrest; intravenous injection of medicine; puncture; central venous catheterization; intraosseous access; intra-arterial; intracardiac routes of administration of medications.

Рукопис надійшов до редакції 10.07.2017 p. 
Відомості про авторів:

Ляхович Роман Мар'янович - к.мед.н., доцент кафедри невідкладної та екстреної медичної допомоги ДВНЗ «Тернопільський державний медичний університет імені І.Я. Горбачевського МОЗ України»; тел.: 0975025342

Джус Михайло Ярославович - директор-головний лікар "Центр екстреної та невідкладної медичної допомоги" Тернопільської обласної ради; тел.: (0352)24-61-63

Кіцак Ярослав Миронович - к.мед.н., доцент кафедри невідкладної та екстреної медичної допомоги ДВНЗ «Тернопільський державний медичний університет імені І.Я. Горбачевського МОЗ України»; тел.: 0971425953

Бадрах Олександр Костянтинович - лікар-анестезіолог Тернопільської міської комунальної лікарні швидкої допомоги; тел.: 0984488187

Савчук Вікторія Миколаївна - магістрант ННІ медсестринства; тел.: 0968277608

Новікова Поліна Петрівна - магістрант ННІ медсестринства; тел.: 0988899350 